\title{
GAYA BAHASA KUMPULAN PUISI FRASA DI PENGHUJUNG MUSIM KARYA ADISKA NIRMAYA DAN KUMPULAN PUISI NAFAS KARYA FATIMA MUSAWA MELALUI PENDEKATAN PERBANDINGAN SASTRA
}

\author{
Agung Nugroho ${ }^{1}$, Inda Puspita Sari ${ }^{2}$ \\ Program Studi Pendidikan Bahasa dan Sastra Indonesia STKIP PGRI Lubuklinggau ${ }^{1,2}$ \\ agung.nugroho12354@gmail.com ${ }^{1}$
}

Submit, 03-05-2019 Accepted, 27-06-2019 Publish,27-06-2019

\begin{abstract}
ABSTRAK
Penelitian ini bertujuan untuk memperoleh pemahaman perbandingan gaya bahasa dalam kumpulan puisi Frasa di Penghujung Musim karya Adiska Nirmaya dan kumpulan puisi Nafaskarya Fatimah Musawa. Metode yang digunakan kualitatif deskriptif.Teknik pengumpulan data dalam penelitian menggunakan teknik dokumentasi. Teknik analisis data dengan langkah-langkah: reduksi data, display data, dan pengambilan kesimpulan dan verifikasi. Hasil penelitian menunjukan terdapat perbandingan gaya bahasa perbandingan dan gaya bahasa pertentangan. Gaya bahasa perbandingan pada kumpulan puisi Frasa di Penghujung Musim karya Adiska Nirmala berjumlah 18 data dan gaya bahasa pertentangan berjumlah 5 data, berdasarkan data gaya bahasa yang mendominasi kumpulan puisi Frasa di Penghujung Musimkarya Adiska Nirmaya adalah gaya bahasa perbandingan. Sedangkan kumpulan puisi Nafas karya Fatimah Musawa yaitu: Gaya bahasa perbandingan seluruhnya berjumlah 9 data.Sedangkan gaya bahasa pertentangan berjumlah 11 data. Simpulan, kumpulan puisi Frasa di Penghujung Musim karya Adiska Nirmaya lebih dominan pada gaya bahasa perbandingan dan kumpulan puisi Nafas karya Fatima Musawa memiliki dominan pada gaya bahasa pertentangan.
\end{abstract}

Kata Kunci: Gaya Bahasa, Kumpulan Puisi.

\section{ABSTRACT}

This study aims to gain an understanding of the comparison of language styles in a collection of End-of-Season Phrases by Adiska Nirmaya and a collection of Nafaskarya Fatimah Musawa poems. The method used is qualitative descriptive. Data collection techniques in research using documentation techniques. Data analysis techniques with steps: data reduction, data display, and conclusion and verification. The results of the study show that there are comparisons of comparative language styles and opposing language styles. Comparative language style in the collection of End-of-Season Phrases by Adiska Nirmala amounts to 18 data and the language style of contention is 5 data, based on the language style that dominates the collection of Phrase Poems at the End of Season. Whereas the collection of Nafas poems by Fatimah Musawa, namely: Language style comparisons totaling 9 data. While the language style of contention is 11 data. Conclusions, a collection of End-of-Season Phrases by Adiska Nirmaya is more dominant in the style of comparison and the collection of Nafas poems by Fatima Musawa has a dominant style of language in opposition.

Keywords: Language Style, Collection of Poetry. 


\section{PENDAHULUAN}

Sastra merupakan salah satu cabang kesenian yang selalu berada dalam peradaban manusia sejak ribuan tahun sebagai wujud gagasan seorang terhadap lingkungan sosial budaya yang berada di sekelilingnya.Sastra bukan hanya sekedar cerita fiksi atau pemikiran pengarang saja, melainkan wujud dari kreativitas pengarang dalam menggali dan mengelolah gagasan yang ada dalam pikirannya sehingga menjadi suatu karya yang indah.Sehingga memberikan kepuasan estetika bagi khalayak pembaca, karya sastra selalu bersifat subjektif tidak pernah terlepas deri hakikatnya yang imajinatif. Menurut Suyitno (2009) Sastra mengutamakan perasaan dan renunganrenungan batin mengajak manusia agar lebih peka dan tertarik terhadap hal-hal yang bersifat estetik dan rohanian".

Sastra merupakan wujud gagasan seseorang melalui pandangan terhadap lingkungan sosial yang berada di sekelilingnya dengan menggunakan bahasa yang indah. Sastra hadir untuk sebagai hasil perenungan pengarang terhadap fenomena yang ada. Karyasastra merupakan refleksi rasa dan karsa berarti bahwa karya sastra diciptakan untuk menyatakan perasaan yang di dalamnya terkandung maksud atau tujuan tertentu ini membuat karya sastra memiliki kelebihan dibandingkan dengan cabang seni lain, baik dalam bentuk maupun sarana atau media yang digunakan, yaitu kata atau bahasa salah satu pendekatan karya sastra adalah sastra perbandingan.

Sohaimi (Endaswara, 2014) menyatakan "Sastra bandingan lebih berpijak pada penelitian antardisiplin dengan teori dan pendekatan yang jelas”. Sedangkan Damono (2015) menjelaskan Sastra bandingan adalah pendekatan dalam ilmu sastra yang tidak menghasilkan teori tersendiri, dapat dikatakan teori apapun bisa dimanfaatkan dalam penelitian sastra bandingan sesuai dengan obyekdan tujuan penelitiannya. Bandingan itu sendiri merupakan pendekatan dalam ilmu sastra yang lebih berpijak pada penelitian antar disiplin dengan dimanfaatkan sesuai obyek dan tujuannya. Berdasarkan teori tersebut penulis membandingkan gaya bahasa pada kumpulan puisi.

Menurut Ilyas (2011) Puisi adalah hasil cipta manusia yang terdiri atas beberapa baris (lirik) yang memperhatikan makna dan membentuk bait. Emerson (Tarigan, 2009) Puisi merupakan upaya abadi untuk mengekspresikan jiwa sesuatu yang berguna untuk menggerakkan tubuh yang kasar dan mencari kehidupan dan alasan yang 
menyebabkannya ada. Puisi diartikan "Ragam sastra yang bahasanya terikat oleh rima dan tata puitika yang lain (Zaidan, 2007). Kumpulan puisi yang dibandingkan dalam penelitian ini adalahkumpulan puisi Frasa di Penghujung Musim karya Adiska Nirmaya dan kumpulan puisi Nafas karya Fatimah Musawa.

Karya sastra jenis puisi dapat dikaji dari macam unsurnya. Unsur yang dikaji dapat ditinjau dari unsure fisik dan unsure batin puisi. Unsur fisik puisi meliputi imaji, kata konkret, pilihan kata atau diksi, bahasa figuratif, tipografi dan rima. Sedangkan unsure batin pada puisi meliputi tema, nada, rasa, dan amanat. Penelitian ini memfokuskan pada gaya bahasa (majas) yang terdapatdalam unsure fisik pada puisi.

Menurut Wirajaya (2009) bahwa gaya bahasa merupakan cara mengungkapkan pikiran melalui bahasa secara khas yang memperlihatkan jiwa dan kepribadian penulis (pemakaianbahasa). Keraf (Nurhasanah, 2017) menjelaskan gaya bahasa adalah cara mengungkapkan pikiran melalui bahasa secara khas dengan memperhatikan jiwa dan kepribadian penulis (pemakai bahasa). Sebuah gaya bahasa yang baik harus mengandung tiga unsur yang meliputi kejujuran, sopan santun, dan menarik. Sebuah puisi, gaya bahasa itu sangat menarik untuk dipelajari karena gaya bahasa dapat menjadikan ciri khas yang menggambarkan kepribadian setiap penulisnya masingmasing.

Kumpulan puisi yang berjudul Frasa di Penghujung Musim karya Adiska Nirmaya dan kumpulan puisi Nafas karya Fatima Nusawa ini gaya bahasa yang digunakannya ini cukup beraneka ragam yang membuat puisi ini sangat menarik untuk diteliti dan gaya bahasa pada kedua kumpulan puisi ini menimbulkan kesan-kesan tertentu yang dapat menarik para pembacanya. Kedua pengarang puisi yang diteliti ini dapat dikatakan bahwa pengarang menuangkan ide dan persaannya ke dalam kumpulan puisi yang memakai gaya bahasa yang semenarik mungkin sesuai dengan persaan masing-masing pengarang. Dari hal ini gaya bahasa kedua kumpulan puisi dibandingkan sehingga pembaca lebih memahami makna yang terkandung dari setiap puisinya.

Penelitian ini relevan dengan penelitian Mualim dan Erowati (2015) dengan judul Perbandingan Gaya Bahasa pada Puisi “Ibu” karya Mustofa Bisri dengan Lirik Lagu "Keramat" karya Rhoma Irama. Perasamaan penelitiannya sama-sama mengkaji 
gaya bahasa sedangkan perbedaannya pada puisi yang menjadi objek penelitian. Pada penelitian relevanmengkaji keseluruhan gaya bahasa pada puisi Ibu karya Mustofa Bisri dan lirik laguKeramat karya Rhoma Irama sedangkan penelitian ini hanya membandingkan gaya bahasa perbandingan dan pertentangan pada puisi Frasa di Penghujung Musim karya Adiska Nirmaya dan puisi Nafas karya Fatima Nusawa.

\section{METODE PENELITIAN}

Metode penelitian ini adalah metode kualitatif dengan menggunakan metode deskriptif. Sugihastuti (2016) mengatakan pendekatan kualitatif ialah pendekatan penelitian naturalistik karena penelitianya dilakukan pada kondisi yang alamiah. Sedangkan Riyanto (2010) menjelaskan metode deskriptif adalahpenelitian yang diarahkan untuk memberikan gejala, fakta atau kejadian secara sistematis dan akurat, mengenai sifat populasi atau daerah tertentu. Dalam metode ini objek yang digunakan untuk meneliti yaitu suatu objek, suatu kondisi, suatu sistem pemikiran atau kelas peristiwa pada masa sekarang.

Analisis data dalam penelitian ini lebih ditekankan pada menganalisis gaya bahasa yaitu gaya bahasa perbandingan (Metafora, personifikasi, alegori, perumpamaan, dan depersonifikasi) dan gaya bahasa pertentangan (Hiperbola, litotes, Ironi, oksimoron, dan satire).Kemudian dilanjutkan dengan membandingkan gaya bahasa pada kumpulan puisi Frasa di Penghujung Musim karya Adiska Nirmaya dan kumpulan puisi Nafas karya Fatimah Nusawa dan dilanjutkan menarik kesimpulan perbaningan kedua kumpulan puisi tersebut.

Data dalam penelitian ini tentang analisis gaya bahasa kumpulan puisi Frasa di Penghujung Musim karya Adiska Nirmaya dan kumpulan puisi Nafas karya Fatimah Nusawa. Data penelitian dari kumpulan puisi Frasa di Pegnghujung Musim karya Adiska Nirmaya dari empat judul besar puisi diantaranya Menuliskan Rasa, Menikmati Kisah, Menutup Buku, dan Membuka Lembaran Baru. Dari keempat garis besar yang disebutkan maka penelitian ini akan menganalisis gaya bahasa dari judul puisi menikmati kisah (Seperti Cinta Ia Datang Tanpa Permisi, Waktu Kembar, Pucuk yang Hampir Layu, Merawat Anak Rindu dan Aku Pulang). Sedangkan kumpulam puisi Nafas karya Fatimah Nusawa terdiri dari tiga puluh delapan puisi, maka penelitian ini 
akan menganalisis gaya bahasa dari judul puisi (Kesadaran, Benda Mati, Pagi, Pudar, Sementara).

Untuk mengumpulkan data yang dipergunakan dalam penelitian ini, penulis menggunakan teknik simak dan teknik catat. Teknik simak merupakan cara yang digunakan untuk memperoleh data yang dilakukan dengan cara menyimak penggunaan bahasa. Isitilah ini bukan hanya berkaitan dengan penggunaan bahasa secara lisan tetapi juga penggunaan bahasa secara tertulis. Teknik catat memiliki arti bahwa teknik ini merupakan teknik lanjutan yang dilakukan ketika menerapkan teknik simak. Teknik catat juga sebagai gandengan dari teknik simak, yaitu mencatat beberapa bentuk yang relevan bagi penelitiannya dari penggunaan bahasa secra tertulis tersebut.

Setelah data terkumpul maka selanjutnya peneltian ini akan melakukan analisis atau kajian dengan dengan dua cara untuk menganalisis data, yaitu analisis data simak dan analisis data catat. Saebani (2008) menjelaskan analisis data merupakan proses menyusun data agar dapat diinterpretasi. Maka dibawah ini langkah-langkah analisis data dalam penelitian ini

Analisis ini kegiatan menyimak yang dilakukan saat penelitian kumpulan puisi Frasa di Penguhujung Musim karya Adiska Nirmaya dan kumpulan puisi Nafas karya Fatimah Nusawa dilakukan dengan cara menyimak secara seksama setiap baris, kata pada puisi dalam kumpulan puisi Frasa di Penghujung Musim karya Adiska Nirmaya dan kumpulan puisi Nafas karya Fatimah Nusawa yang akan di analisis atau dikaji tersebut yang kemudian akan melakukan pencatatan.

Hasil catat yang akan dianalisis atau dikaji dilakukan setelah menyimak dan mencatat isi kata atau baris yang terdapat pada puisi yang akan dianalisis menggunakan analisis gaya bahasa mengenai gaya bahasa perbandingan dan gaya bahasa pertentangan dalam kumpulan puisi Frasa di Penghujung Musim karya Adiska Nirmaya dan kumpulan puisi Nafas karya Fatimah Nusawa.

Suatu pertanggungjawaban pada penelitian ini untuk melihat kriteria keabsahan data yang didapatkan oleh penulis, adapun keabsahan data tersebut menurut Sugiyono (2018) yaitu sebagai berikut:Kepercayaan (Credibility), Keteralihan, Kebergantungan dan Kepastian. 


\section{HASIL PENELITIAN}

Analisis gaya bahasa dalam membangun kumpulan puisi Frasa di Penghujung Musim karya Adiska Nirma dan kumpulan puisi Nafas karya Fatima Musawa pada penelitian ini penulis menggunakan gaya bahasa perbandingan (metafora, personifikasi, alegori, perumpamaan dan deperdonifikasi) dan gaya bahasa pertentangan (hiperbola, litotes, ironi, oksimoron, dan satire). Untuk dapat mudah memahaminya dapat dilihat pada penjelasan berikut ini:

\section{Hasil Analisis Gaya Bahasa Perbandingan dalam Kumpulan Puisi Frasa di Penghujung Musim karya Adiska Nirmaya.}

Berdasarkan hasil analisis ditemukan 18 data mengenai jenis gaya bahasa perbandingan yang meliputi gaya bahasa metafora, personifikasi, alegori, perumpamaan, depersonifikasi. Pada kumpulan puisi Frasa di Penghujung Musim karya Adiska Nirmaya khususnya judul puisi Seperti Cinta, Ia Datang Tanpa Permisi, Waktu Kembar, Pucuk yang Hampir Layu, Merawat Anak Rindu, dan Aku Pulang.

\section{Metafora}

Gaya bahasa Metafora dari 5 judul puisi dalam kumpulan puisi Frasa di Penghujung Musim karya Adiska Nirmaya ditemukan 2 kutipan yaitu pada judul Waktu Kembardan Pucuk yang Hampir Layudengan kode kutipan pada larik 002 pada halaman 31 dan kode kutipan 009 pada halaman 32. Pada judul Seperti Cinta, Ia Datang Tanpa Permisi, Merawat Anak Rindu dan Aku Pulang tidak terdapat gaya bahasa metafora. Gaya bahasa metafora melukiskan sesuatu dengan perbandingan secara langsung, dapat dilihat pada beberapa kutipan berikut:

Pada judul Waktu Kembar ditemukan gaya bahasa metafora dengan dapat dilihat pada kutipan berikut:

(002) Cahaya bintang berekor terbang melintas (hal.31)

Kutipan di atas dikategorikan sebagai gaya bahasa metafora, hal ini dapat dilihat dari analisis bahwa kata tersebut merupakan kata singkat yang dapat melukiskan sesuatu dengan makna yang indah dan kata tersebut diibaratkan bahwa bintang tersebut dapat bercahaya.

Sedangkan pada judul Pucuk yang Hampir Layu ditemukan gaya bahasa metafora dapat dilihat pada kutipan berikut: 
(009) Mewangi diantara dua hati (hal.32)

Kutipan di atas dikategorikan sebagai gaya bahasa metafora dikarenakan kutipan tersebut menyatakan suatu kata yang dilukiskan bahwa pada akhirnya suatu rindu dapat terobati dengan sendirinya sehingga dapat menyatukan dirinya dengan seorang yang ditujunya.

\section{Personifikasi}

Gaya bahasa personifikasi dari 5 judul puisi dalam kumpulan puisi Frasa di Penghujung Musim karya Adiska Nirmaya ini ditemukan 9 kutipan yaitu terdapat pada judul Seperti Cinta, Ia Datang Tanpa Permisi terdapat 1 data dengan kode kutipan larik 003 pada halaman 30, pada judul Pucuk yang Hampir Layu terdapat 2 data dengan kode kutipan larik 007 dan 008 pada halaman 32, pada judul Merawat Anak Rindu terdapat 2 data dengan kode kutipan pada larik 001 dan 008 pada halaman 34, serta pada judul $A k u$ Pulang terdapat 4 data dengan kode kutipan pada larik 005, 006, 008, dan 010 pada halaman 37. Gaya bahasa personifikasi menggambarkann benda mati seperti benda hidup, dapat dilihat pada beberapa kutipan berikut:

Pada judul Seperti Cinta, Ia Datang Tanpa Permisi ditemukan gaya bahasa personifikasi. Hal ini dapat dilihat pada kutipan berikut:

(003) Menelantarkan dalam nestapa (hal.30)

Kutipan di atas dikategorikan sebagai gaya bahasa personifikasi karena dapat dianalisis kutipan tersebut benda yang tak bernyawa tapi mengibaratkan hidup atau dapat menelantarkan suatu rindu tersebut.

Pada judul Pucuk yang Hampir Layu ditemukan gaya bahasa personifikasi. Hal ini dapat dilihat pada kutipan berikut:

(007) Membungkuk-bungkuk, mendekat bumi (hal.32)

Kutipan di atas dikategorikan dalam gaya bahasa personifikasi dapat dianalisis karena kata tersebut suatu benda mati yang diibaratkan hidup karena kutipan di samping menyatakan bahwa menahan beban rindu yang semakin menumpuk hingga membugkuk menahan beban rindunya.

(008) Ah! Cepatlah waktu! Tak mau sendiri aku merawatnya (hal.32)

Kutipan di atas dikategorikan sebagai gaya bahasa personifikasi karena dikarenakan kata tersebut menyatakan kata yang diimbaratkan benda hidup. Dalam 
kutipan tersbut juga dinyatakan bahwa waktu segera cepet berjalan karena dirinya tak mau menahan lebih dalam rindu itu.

Pada judul Merawat Anak Rindu ditemukan gaya bahasa personifikasi. Hal ini dapat dilihat pada kutipan berikut:

(001) Meniduri rindu, adalah kesalahan (hal.34)

Kutipan di atas dapat dikategorikan sebagai gaya bahasa personifikasi karena kutipan tersebut seolah-olah benda hidup yang mengibaratkan rindu dapat ditiduri.

(008) Di saat kecewa menyerang rasa dengan cepat (hal.34)

Kutipan di atas dapat dikategorikan dengan gaya bahasa personifikasi dengan kata yang menonjol yaitu kata menyerang. Kata tersebut seolah-olah benda yang mati dapat diibaratkan menjadi benda hidup yang dapat menyerang suatu kekecewaan dengan cepat.

Pada judul Aku Pulang ditemukan gaya bahasa personfikasi. Hal ini dapat dilihat pada kutipan berikut:

(005) Disambut ruang tamu yang ditunggui rindu (hal.37)

Berdasarkan kutipan pada larik 005 tersebut termasuk dalam gaya bahasa personifikasi yang di wakilkan kata yang menonjol yaitu kata ditunggui dikarenakan kata tersebut seolah-olah kata yang seperti benda hidup karena ruang tamu dapat menunggu kerinduan.

(006) Bantal dan sofanya manja mengeloniku sampai tidur (hal.37)

Berdasarkan kutipan pada larik 006 termasuk dalam gaya bahasa personifikasi dengan kata yang menonjol yaitu kata mengeloniku. Kata tersebut menyatakan suatu beda yang mati seola-olah menjadi benda hidup yang dinyatakan pada kutipan disamping bahwa bantal dan sofa dapat menemaniku sampai aku tertidur.

(008) Bersambut secangkir teh beraroma melati (hal.37)

Berdasarkan kutipan pada larik 008 disamping termasuk dalam gaya bahasa personifikasi dengan kata yang menonjol yaitu kata memenuhi. Kata tersebut dinyatakan bahwa secangkir air teh yang beraroma wangi dapat mengharumkan seluruh ruangan.

(010) melahirkan kenyamanan tanpa nama (hal.37) 
Berdasarkan kutipan pada larik 010 disamping termasuk dalam gaya bahasa personifikasi dengan kata yang menonjol yaitu kata melahirkan. Kata tersebut menyatakan bahwa rindu dapat melahirkan sebuah kenyamanan.

\section{Alegori}

Gaya bahasa Alegori dari 5 judul puisi dalam kumpulan puisi Frasa di Penghujung Musim karya Adiska Nirmaya ditemukan 3 kutipan yaitu pada judul Waktu Kembar,Pucuk yang Hampir Layu dan Aku Pulang. Kode kutipan pada judul Waktu Kembar dengan kode kutipan pada larik 001 pada halaman 31, pada judul Pucuk yang Hampir Layu dengan kode kutipan larik 002 pada halaman 32 dan pada judul Aku Pulang dengan kode kutipan pada larik 014 pada halaman 37. Gaya bahasa Alegori menggambarkan cerita yang dikisahkan dalam bentuk lambang-lambang serta obyekobyek.

Pada judul Waktu Kembar ditemukan gaya bahasa alegori. Hal ini dapat dilihat pada kutipan:

(001)Saat jam dinding berdentang, 11 lewat 11 (hal.31)

Pada kutipan di atas dikategorikan kedalam gaya bahasa alegori karena kata yang menonjol dalam gaya bahasa tersebut pada kutipan saat jam dinding. Dapat dianalisis bahwa kutipan tersebut dapat melambangkan sesuatu benda lewat suatu isi cerita puisi.

Pada judul Pucuk yang Hampir Layu ditemukan gaya bahasa alegori. Hal ini dapat dilihat pada kutipan:

(002) Pucuk rindu di punggungnya (hal.32)

Berdasarkan kutipan pada larik 002 tersebut termasuk dalam gaya bahasa alegori. Kata yang menonjol dalam gaya bahasa tersebut pada kata di punggungnya. Dapat dianalisis bahwa kata di punggungnya hanya melambang suatu benda atau objek dikarenaka suatu rindu yang sedang memuncak kini berada di dalam salah satu bebannya.

Pada judul Aku Pulang ditemukan gaya bahasa alegori. Hal ini dapat dilihat pada kutipan:

(014) Inikah rasanya bertemu rumah, saat menatap matamu (hal.37) 
Berdasarkan kutipan pada larik 014 termasuk dalam gaya bahasa alegori dengan kata yang menonjol yaitu kata rumah. Kata tersebut melambangkan suatu objek pada isi puisi tersebut bahwa kata rumah suatu objek tempat yang selalu dirindukannya saat dirinya menatap mata seseorang.

\section{Perumpamaan}

Gaya bahasa Perumpamaan dari 5 judul puisi dalam kumpulan puisi Frasa di Penghujung Musim karya Adiska Nirmaya ditemukan 2 kutipan yaitu pada judul Seperti Cinta, Ia Datang Tanpa Permisi dengankode kutipan pada larik 001 dan 002. Pada judul Waktu kembar, Pucuk yang hampir layu, Merawat anak rindu, dan Aku pulang tidak ditemukan gaya bahasa perumpamaan. Gaya bahasa perumpamaan menggambarkan gaya bahasa yang membandingkan dua hal yang berlainan tapi dianggap sama. Gaya bahasa ini ditandai oleh penggunaan kata bagai, bagaikan, seumpama, seperti.

Pada judul Seperti Cinta, Ia Datang Tanpa Permisi ditemukan gaya bahasa perumpamaan. Hal ini dapat dilihat pada kutipan berikut:

(001)Serupa pencuri tengah malam rindu datang (hal.30)

Berdasarkan kutipan pada larik 001 tersebut termasuk dalam gaya bahas perumpamaan. Kata yang menonjol dalam gaya bahasa tersebut pada kata serupa. Dapat dianalisis bahwa kata yang menonjol pada gaya bahasa tersenut menunjukan kata yang mengumpamakan seorang yang rindu datang kembali pada malam itu.

(002) Menyergap dalam sekejap (hal.30)

Berdasarkan kutipan pada larik 002 tersebut termasuk dalam gaya bahasa perumpamaan. Kata yang menonjol dalam gaya bahasa tersebut pada kata sekejap. Dapat dianalisis bahwa kata yang menonjol pada gaya bahasa tersebut merupakan kata yang mengumpamakan bahwa menyerang suatu rindu dengan cepat.

\section{Depersonifikasi}

Gaya bahasa Depersonifikasi dari 5 judul puisi dalam kumpulan puisi Frasa di Penghujung Musim karya Adiska Nirmaya ditemukan 2 kutipan yaitu pada judul Merawat Anak Rindudengankode kutipan pada larik 004 dan 005. Pada judul Waktu kembar, Pucuk yang hampir layu, Seperti Cinta Ia Datang Tanpa Permisi, dan Aku pulang tidak ditemukannya gaya bahasa depersonifikasi. Gaya bahasa depersonifikasi 
ini terdapat dalam kalimat pengandaian yang secara eksplisit memanfaatkan kata kalau dan sejenisnya.

Pada judul Merawat Anak Rindu ditemukan gaya bahasa deperso nifikasi. Hal ini dapat dilihat pada kutipan:

(004) Nyaman nian kala berada di pelukan (hal.34)

Berdasrkan kutipan larik 004 tersebut merupakan gaya bahasa depersonifikasi dengan kata yang menonjol yaitu kata kala dikarenakan kata pada kutipan tersebut sebagai salah satu pengandaian yang secara eksplisit dengan ditambahnya kata kala.

(005) Tapi kini, entah sisi mana yang ditampilkan (hal.34)

Berdasrkan kutipan pada larik 005 tersebut merupakan gaya bahasa depersonifikasi. Kata yang menonjol pada gaya bahasa tersebut yaitu kata kini karena kata tersebut salag satu kata pengandaian dakam suatu kalimat yang ditambahkan dengan kata kini sebagai salah satu kata hubung.

\section{Hasil Analisis Gaya Bahasa Pertentangan dalam Kumpulan Puisi Frasa di Penghujung Musim karya Adiska Nirmaya. Hiperbola}

Gaya bahasa Hiperbola dari 5 judul puisi dalam kumpulan puisi Frasa di Penghujung Musim karya Adiska Nirmaya ini ditemukan 4 kutipan yaitu terdapat pada judul Waktu Kembar dengan kode kutipan pada larik 002, pada judul Pucuk yang Hampir Layu dengan kode kutipan pada larik 006 , pada judul Merawat Anak Rindu dengan kode kutipan larik 007, dan pada judul Aku Pulang dengan kode kutipan pada larik 009. Gaya bahasa hiperbola menggambar sesuatu hal yang berlebih-lebihan.

Pada judul Waktu Kembar ditemukan gaya bahasa hiperbola. Hal ini dapat dilihat pada kutipan berikut:

(002) Cahaya bintang berekor terbang melintas (hal.31)

Berdasrkan kutipan pada larik 002 tersebut termasuk dalam gaya bahasa hiperbola. Kata yang menojol dalam gaya bahasa tersebut pada kutipan cahaya bintang berekor. Dapat dianalisis bahwa kutipan tersebut merupak kata yang berlebihan diibaratkan bintang yang sedang bercahya dapat berekor atau bercabang. Namun kutipan tersebut memiliki makna tersendiri. 
Pada judul Pucuk yang Hampir Layu ditemukan gaya bahasa hiperbola. Hal ini dapat dilihat pada kutipan berikut:

(006) Rindu perlahan semakin pekat (hal.32)

Berdasrkan kutipan pada larik 006 tersebut termasuk dalam gaya bahasa hiperbola. Kata yang menonjol dalam gaya bahasa tersebut pada kata semakin berat. Oleh karena itu kutipan disamping tersebut menyatakan bahwa suatu rindu yang datang secara perlahan semakin berat untuk di simpan. Kata yang menonjol pada gaya bahasa tersebut merupakan kata yang berlebihan.

Pada judul Merawat Anak Rindu ditemukan gaya bahasa hiperbola. Hal ini dapat dilihat pada kutipan berikut:

(007) Dengan malam yang paling pekat (hal.34)

Berdasarkan kutipan pada larik 007 termasuk dalam gaya bahasa hiperbola dengan kata yang menonjol yaitu kata yang paling pekat. Kata pada kutipan tersebut merupakan kata yang melebih-lebihkan akan suatu hal oleh karena itu kutipan disamping menyatakan bahwa sedang merawat rindu di malam yang paling pahit.

Pada judul Aku Pulang ditemukan gaya bahasa hiperbola. Hal ini dapat dilihat pada kutipan berikut:

(009) Dari ketel beruap di dapur (hal.37)

Berdasarkan kutipan pada larik 009 disamping termasuk dalam gaya bahasa hiperbola. Kata yang menonjol yaitu kata beruap. Kata tersebut merupakan kata yang berlebihan sehingga dari asap secangkir teh dapat beruap memenuhi ruang dapur.

\section{Litotes}

Gaya bahasa Litotes dari 5 judul puisi dalam kumpulan puisi Frasa di Penghujung Musim karya Adiska Nirmaya ini tidak ditemukannya gaya bahasa litotes walaupun dari berbagai macam judul yang menjadi fokus pada penelitian ini, penulis tidak menemukan gaya bahasa litotes tersebut.

\section{Ironi}

Gaya bahasa Ironi dari 5 judul puisi dalam kumpulan puisi Frasa di Penghujung Musim karya Adiska Nirmaya ini tidak ditemukannya gaya bahasa ironi tersebut. Dari kelima judul yang menjadi fokus pada penelitian ini juga penulis tidak menemukan satupun gaya bahasa ironi tersebut. 


\section{Oksimoron}

Gaya bahasa Oksimoron dari 5 judul puisi dalam kumpulan puisi Frasa di Penghujung Musim karya Adiska Nirmaya ini sama seperti gaya bahasa litotes dan gaya bahasa ironi yang tidak sama sekali ditemukan. Pada analisis penelitian ini, penulis dalam kelima judul yang menjadi subfokus penelitian tidak adanya menemukan gaya bahasa oksimoron yang terdapat pada kumpulan puisi Frasa di Penghujung Musim karya Adiskan Nirmaya dengan judul besar yang menjadi fokus yaitu judul Menikmati Kisah.

\section{Satire}

Gaya bahasa Satire dari 5 judul puisi dalam kumpulan puisi Frasa di Penghujung Musim karya Adiska Nirmaya ini ditemukan 1 kutipan yaitu terdapat pada judul Merawat Anak Rindu dengan kode kutipan pada larik 005 halaman 34. Gaya bahasa satire sejenis bentuk argumen yang beraksi scara tidak langsung, terkadang secara aneh.

Pada judul Merawat Anak Rindu ditemukannya gaya bahasa satire. Hal ini dapat dilihat pada kutipan berikut ini:

(005) Lama-lama ia akan mempermainkanmu (hal.34)

Berdasrkan kutipan pada larik 005 disamping merupakan gaya bahasa satire dengan kata yang menonjol yaitu kata mempermainkanmu. Kata pada kutipan tersebut menyatakan sejenis tindakan yang dinyatakan secara tidak langsung.

\section{Hasil Gaya Bahasa Perbandingan Kumpulan Puisi Nafas karya Fatima Musawa. Metafora}

Gaya bahasa Metafora dari 5 judul puisi dalam kumpulan puisi Nafas karya Fatima Musawa ini ditemukan 1 kutipan yaitu terdapat pada judul Benda Mati dengan kode kutipan pada larik 003 halaman 35. Gaya bahasa metafora melukiskan sesuatu dengan perbandingan secara langsung, dapat dilihat pada analisis.

Pada judul Benda Matiditemukan gaya bahasa metafora dengan dapat dilihat pada kutipan berikut:

(003) Seperti sebutir debu yang terserap keluasan bumi (hal.35) 
Berdasarkan kutipan pada larik 003 disamping termasuk ke dalam gaya bahasa metafora dengan kata yang menonjol yaitu kata sebutir debu. Kata tersebut menyatakan bahwa masalah yang kecilpun dapat hilang dengan luasnya bumi.

\section{Personifikasi}

Gaya bahasa Personifikasi dari 5 judul puisi dalam kumpulan puisi Nafas karya Fatima Musawa ini ditemukan 3 kutipan yaitu terdapat pada judul Kesadarandengan kode kutipan pada larik 004 halaman 21, pada judul Pagi dengan kode kutipan pada larik 002 halaman 47, dan pada judul Pudar dengan kode kutipan larik 003 halaman 93.Gaya bahasa personifikasi menggambarkan benda mati seperti benda hidup, dapat dilihat pada hasil analisis.

Pada judul Kesadaran ditemukan gaya bahasa personifikasi. Hal ini dapat dilihat pada kutipan berikut:

(004) Sedangkan hati dan jiwanya tercabik-cabik oleh derita kehidupan fana? (hal.21)

Berdasarkan kutipan di atas pada larik 004 disamping termasuk kedalam gaya bahasa personifikasi dimana kutipan yang menonjol yaitu hati dan jiwanya tercabikcabik. Kata tersebut menyatakan bahwa hati dan jiwa yang sedang terpukul dengan derita hidup yang keras.

Pada judul Pagi ditemukan gaya bahasa personifikasi. Hal ini dapat dilihat pada kutipan berikut:

(002) Angin menghembuskan salam selamat pagi yang indah nan mulia (hal.47)

Berdasrkan kutipan pada larik 002 disamping termasuk dalam gaya bahasa personifikasi. Kata yang menonjol pada kutipan disamping yaitu kata angin menghembuskan. Kata tersebut dapat dikatakan gaya bahasa personifikasi menyatakan bahwa pada suatu pagi datang datanglah angin menghembuskan keceriaan.

Pada judul Pudar ditemukan gaya bahasa personifikasi. Hal ini dapat dilihat pada kutipan berikut:

(003) Kau bintang yang meragukan (hal.93)

Berdasarkan kutipan pada larik 003 disamping termasuk kedalam gaya bahasa personifikasi dengan kata yang menonjol yaitu kata meragukan. Kata tersebut 
menyatakan bahwa benda mati seolah hidup, seperti pada kutipan disamping bahwa bintang yang bisa meragukan.

\section{Alegori}

Gaya bahasa Alegori dari 5 judul puisi dalam kumpulan puisi Nafas karya Fatima Musawa ini ditemukan 1 kutipan yaitu terdapat pada judul Pagi dengan kode kutipan pada larik 001 halaman 47. Gaya bahasa Alegori menggambarkan cerita yang dikisahkan dalam bentuk lambang-lambang serta obyek-obyek.

Pada judul Kesadaran ditemukan gaya bahasa personifikasi. Hal ini dapat dilihat pada kutipan berikut:

(001)Para burung bersenandung ceria (hal.47)

Berdasarkan kutipan pada larik 001 disamping termasuk dalam gaya bahasa alegori. Kata yang menonjol pada kutipan tersebut yaitu kata para burung. Kata tersebut menyatakan bahwa melambangkan suatu hal atau objek yang dituju pada isi puisi atau isi larik puisi tersebut.

\section{Perumpamaan}

Gaya bahasa Perumpamaan dari 5 judul puisi dalam kumpulan puisi Nafas karya Fatima Musawa ini ditemukan 3 kutipan yaitu terdapat pada judul Benda Matidengan kode kutipan pada larik 002 halaman 35, pada judul Pudar dengan kode kutipan pada larik 001 pada halaman 93 , dan pada judul Sementara dengan kode kutipan pada larik 007pada halaman 161. Gaya bahasa perumpamaan menggambarkan gaya bahasa yang membandingkan dua hal yang berlainan tapi dianggap sama. Gaya bahasa ini ditandai oleh penggunaan kata bagai, bagaikan, seumpama, seperti.

Pada judul Benda Matiditemukan gaya bahasa perumpamaan. Hal ini dapat dilihat pada kutipan berikut:

(002) Seperti benda mati, dibawah kerajaan Sang Ilahi (hal.35)

Berdasarkan kutipan pada larik 002 disamping termasuk dalam gaya bahasa perumpamaandengan kata yang menonjol yaitu kata seperti. Kata tersebut mengumpamakan benda mati yang berada dibawah kerajaan Sang Ilahi.

Pada judul Pudarditemukan gaya bahasa perumpamaan. Hal ini dapat dilihat pada kutipan berikut:

(001)Kau seakan bintang yang pudar sebab sinar mentari (hal.93) 
Berdasarkan kutipan pada larik 001 disamping termasuk gaya bahasa perumpamaan dengan kata yang menonjol yaitu kata seakan. Kata tersebut menyatakan bahwa dirinya mengibaratkanseseorang yang lemah karena orang lain.

Pada judul Sementaraditemukan gaya bahasa perumpamaan. Hal ini dapat dilihat pada kutipan berikut:

(007) Aku seakan tak berarti (hal.161)

Berdasarkan kutipan pada larik 007 disamping termasuk gaya bahasa perumpamaan dengan kata yang menonjol yaitu kata seakan. Kata tersebut sebagai salah satu untuk mengumpamakan bahwa dirinya seakan atau ibaratkan tak ada artinya.

\section{Depersonifikasi}

Gaya bahasa Depersonifikasi dari 5 judul puisi dalam kumpulan puisi Nafas karya Fatima Musawa ini ditemukan 1 kutipan yaitu terdapat pada judul Benda Mati dengan kode kutipan pada larik 008 pada halaman 35. Gaya bahasa depersonifikasi ini terdapat dalam kalimat pengandaian yang secara eksplisit memanfaatkan kata kalau dan sejenisnya.

Pada judul Benda Mati ditemukan gaya bahasa depersonifikasi. Hal ini dapat dilihat pada kutipan berikut:

(008) Dia yang telah mencintaiku, sebelum aku bahkan dapat berfikit untuk mencintai-Nya (hal.35)

Berdasarkan kutipan pada larik 008 disamping termasuk ke dalam gaya bahasa depersonifikasi dikarenakan kata yang menonjol pada kutipan disamping yaitu kata bahkan. Dari kata tersebut menyatakan bahwa kata tersebut dapat menghubungan dari kata ke kata yang lain sehingga terbentuknya suatu kalimat yang memiliki makna.

\section{Hasil Analisis Gaya Bahasa Pertentangan dalam Kumpulan Puisi Nafas karya Fatima Musawa. \\ Hiperbola}

Gaya bahasa Hiperbola dari 5 judul puisi dalam kumpulan puisi Nafas karya Fatima Musawa ini ditemukan 3 kutipan yaitu terdapat pada judul Kesadaran dengan kode kutipan pada larik 002 dan 003 pada halaman 21 serta judul Benda Mati dengan kode kutipan pada larik 007 pada halaman 35. Gaya bahasa hiperbola menggambar sesuatu hal yang berlebih-lebihan sehingga kata tersebut memiliki makna yang indah. 
Pada judul Kesadaran ditemukan gaya bahasa perumpamaan. Hal ini dapat dilihat pada kutipan berikut:

(002) Bagaimana jutaan manusia dapat bertahan dengan memendam begitu banyak rasa dan sakit di dalamnya (hal.21)

Berdasarkan kutipan pada larik 002 disamping termasuk dalam gaya bahasa hiperbola. Kata yang menonjol dalam gaya bahasa hiperbola pada kutipan disamping yaitu kata jutaan manusia. Dapat dinyatakan bahwa kata tersebut kata yang dapat melebih-lebihkan akan sesuatu hal.

(003) Bagaimana seseorang tetap hidup dengan terus menelan jeritan pilu dan air mata luka (hal.21)

Berdasarkan kutipan pada larik 003 disamping termasuk ke dalam gaya bahasa hiperbola kutipan yang menonjol dalam gaya bahasa tersebut yaitu kutipan menelan jeritan pilu dan air mata luka. Kata tersebut menyatakan bahwa seseorang bertahan hidup dengan menahan luka dan air mata.

Pada judul Benda Mati ditemukan gaya bahasa perumpamaan. Hal ini dapat dilihat pada kutipan berikut:

(007) Terkadang setelah jatuh aku terinjak-injak oleh jejak (hal.35)

Berdasarkan kutipan pada larik 007 disamping termasuk dalam gaya bahasa hiperbola karena gaya bahasa hiperbola yang menonjol pada kutipan disamping terdapat kutipan terinjak-injak oleh jejak kaki masalah. Dari kutipan disamping dapat dianalisis bahwa seseorang yang hidupnya sering terjatuh karena masalah yang mendalam.

\section{Litotes}

Gaya bahasa Litotes dari 5 judul puisi dalam kumpulan puisi Nafas karya Fatima Musawa ini ditemukan 3 kutipan yaitu terdapat pada judul Benda Matidengan kode kutipan pada larik 005 dan 007 pada halaman 35 serta judulSementaradengan kode kutipan pada larik 008 pada halaman 161. Gaya bahasa litotes merupakan majas yang mengungkapkan sesuatu dengan cara berlawanan dari kenyataan dengan mengecilkan dengan bertujuan untuk merendahkan diri.

Pada judul Benda Matiditemukan gaya bahasa perumpamaan. Hal ini dapat dilihat pada kutipan berikut:

(005) Akulah si mayit, di bawah kendali Sang Pemandi (hal.35) 
Berdasarkan kutipan pada larik 005 disamping merupakan gaya bahasa litotes yang menyatakan bahwa kutipan tersebut meruapakan kutipan yang merendahkan dirinya.

(007) Akupun Sang Daun, yang terus terjatuh untuk hembusan angin (hal.35)

Berdasarkan kutipan pada larik 007 disamping termasuk kedalam gaya bahasa litotes karena kutipan tersebut menyatakan bahwa sedang merendahkan dirinya sendiri. Dalam kutipan disamping terlihat bahwa dirinya yang hanya sebagai sehelai sang daun yang sering dijatuhkan oleh angin dapat dimaknakan bahwa dirinya hanya sebagai manusia biasa yang selalu mendapat cemoohan orang lain.

Pada judul Sementaraditemukan gaya bahasa perumpamaan. Hal ini dapat dilihat pada kutipan berikut:

(008) Hanyalah seorang aku, yang dapat kau permainkan sesuka hati (hal.161)

Berdasarkan kutipan pada larik 008 disamping merupakan gaya bahasa litotes dikarenakan kutipan tersebut menyatakan bahwa hanya seorang dirinya yang selalu disakiti sesuka hati lelaki itu.

\section{Ironi}

Gaya bahasa Ironi dari 5 judul puisi dalam kumpulan puisi Nafas karya Fatima Musawa ini ditemukan 3 kutipan yaitu terdapat pada judul Pudar dengan kode kutipan pada larik 004, 006, dan 008 pada halaman 93. Gaya bahasa Ironi merupakangaya bahasa yang mengungkapkan sesuatu yang bertentangan yang sebenarnya yang bermaksud untuk berolok-olok.

Pada judul Pudarditemukan gaya bahasa perumpamaan. Hal ini dapat dilihat pada kutipan berikut:

(004) Kau ada, tapi kesungguhanmu dipertanyakan (hal.93)

Berdasarkan kutipan pada larik 004 disamping merupakan gaya bahasa ironi dikarenakan kutipan tersebut menyatakan bhawa kutipan yang mengungkapkan sesuatu hal dengan berolok-olok, seperti pada kutipan disamping memiliki makna seseorang itu ada tapi kenyataannya masih meragukan.

(006) Menemukanmu adalah impian, tapi keaslianmu nyaris tak dipercaya (hal.93) 
Berdasarkan kutipan pada larik 006 disamping termasuk dalam gaya bahasa ironi dikarenakan kutipan tersebut menyatakan bahwa bertemu dengan seseorang suatu hal yang diimpikan tetapi kenyataan seseorang susah untuk di percaya.

(008) Kau bagai Fatamorgana. Terlihat, dan ada tapi tak nyata (hal.93)

Berdasarkan kutipan pada larik 008 disamping termasuk gaya bahasa ironi dikarenakan kutipan disamping menyatakan bahwa seseorang bagaikan pemandangan yang terlihat dan selaluada tapi wujud nya belum nyata.

\section{Oksimoron}

Gaya bahasa Oksimoron dari 5 judul puisi dalam kumpulan puisi Nafas karya Fatima Musawa ini ditemukan 1 kutipan yaitu terdapat pada judul Sementara dengan kode kutipan pada larik 002 halaman 161. Gaya bahasa oksimoron sejenis gaya bahasa yang mengandung penegasan atau pendirian suatu hubungan sintaksis, baik koordinasi maupun determinasi.

Pada judul Sementaraditemukan gaya bahasa perumpamaan. Hal ini dapat dilihat pada kutipan berikut:

(002) Lalu kau hempaskan aku ke dalam jurang acuh dan keasinganmu (hal.161)

Berdasarkan kutipan pada larik 002 disamping termasuk dalam gaya bahasa oksimoron dengan kata yang menonjol yaitu kata hempaskan dikarenakan kata pada kutipan tersebut sebuah kata penegasan pada isi larik puisi tersebut.

\section{Satire}

Gaya bahasa Satire dari 5 judul puisi dalam kumpulan puisi Nafas karya Fatima Musawa ini ditemukan 1 kutipan yaitu terdapat pada judul Benda Matidengan kode kutipan pada larik 006 halaman 35. Gaya bahasa satire sejenis bentuk argumen yang beraksi scara tidak langsung, terkadang secara aneh.

Pada judul Benda Matiditemukan gaya bahasa perumpamaan. Hal ini dapat dilihat pada kutipan berikut:

(006) Di bolak-balik alur kehidupanku oleh-Nya. Dan bukanlah kuasaku menuntut goresan takdir-Nya (hal.35) 
Berdasarkan kutipan pada larik 006 disamping termasuk dalam gaya bahasa satire dikarenakan kutipan tersebut menyatakan bahwa Tuhan sedang memutarkan kehidupannya. Kata yang menonjol pada kutipan tersebut yaitu kata dibolak-balik.

\section{PEMBAHASAN}

Perbandingan antara kumpulan puisi Frasa di Penghujung Musim karya Adiska Nirmaya dan kumpulan puisi Nafas karya Fatima Musawa sudah jelas bahwa kedua kumpulan puisi ini sangat jauh berbeda. Dapat dibandingkan dalam penelitian ini penulis dapat membandingkan bahwa kumpulan puisi Frasa di Penghujung Musim karya Adiska Nirmaya isinya lebih mengarah ke arah suatu percintaan yang sedih bahkan dapat dikatakan suram. Setelah dianalisis penulis juga sulit mendapatkan gaya bahasa yang banyak pada kumpulan puisi Frasa di Penghujung Musim karya Adiska Nirmaya.

Sedangkan kumpulan puisi Nafas karya Fatima Musawa isi puisinya lebih menggambarkan tentang kehidupan dan tentang agama. Kumpulan puisi Nafas ini peneliti sedikit berbeda dalam menganalisis gaya bahasanya dengan menganalisis gaya bahasa pada kumpulan puisi Frasa di Penghujung Musim karya Adiska Nirmaya karena kumpulan puisi Nafas ini lebih banyak mendapatkan gaya bahasanya

Perbandingan gaya bahasa pada kumpulan puisi Frasa di Penghujung Musim karya Adiska Nirmaya dan kumpulan puisi Nafas karya Fatima Musawa di lihat dari gaya bahasa perbandingan. Berdasarkan hasil analisis ditemukan perbandingan dominan pada gaya bahasa perbandingan yaitu 18 data mengenai jenis gaya bahasa perbandingan yang meliputi gaya bahasa metafora, personifikasi, alegori, perumpamaan, depersonifikasi. Pada kumpulan puisi Frasa di Penghujung Musim karya Adiska Nirmaya khususnya judul puisi Seperti Cinta, Ia Datang Tanpa Permisi, Waktu Kembar,Pucuk yang Hampir Layu, Merawat Anak Rindu, dan Aku Pulang. Sedangkan kumpulan puisi Nafas karya Fatima Musawa ditemuka gaya bahasa perbandingan 11 kutipan, jadi berdasarkan hasil kumpulan puisi Frasa di Penghujung Musim karya Adiska Nirmaya lebih kental akan gaya bahasa perbandingan. 


\section{SIMPULAN}

Berdasarkan hasil analisis gaya bahasa terhadap kumpulan puisi Frasa di Penghujug Musim karya Adiska Nirmaya dan kumpulan puisi Nafas karya Fatima Musawa dapat disimpulkan sebagai berikut:

Berdasarkan hasil analisis kumpulan puisi Frasa di Penghujung Musim karya Adiska Nirmaya diketahui bahwa analisis ini terdapat 18 gaya bahasa perbandingan. Gaya bahasa tersebut, yaitu gaya bahasa, metafora personifikasi, depersonifikasi, alegori, hiperbola, litotes, ironi, oksimoron, dan satire.Gaya bahasa pertentangan pada kumpulan puisi Frasa di Penghujung Musim karya Adiska ditemukan 5 gaya bahasa yang meliputi gaya bahasa hiperbola, dan satire. Gaya bahasa litotes, ironi, dan oksimoron pada kumpulan puisi Frasa di Penghujung Musim karya Adiska Nirmaya tidak ditemukan.

Gaya Bahasa perbandingan pada kumpulan puisi Nafas karya Fatima Musawa ditemukan 9 data yaitu meliputi gaya bahasa metafora, personifikasi, perumpamaan, alegori dan depersonifikasi. Gaya bahasa pertentangan pada kumpulan puisi Nafas karya Fatima Musawa ditemukannya 11 data yang meliputi gaya bahasa hiperbola, litotes, ironi, oksimoron dan gaya bahasa satire. Gaya bahasa pertentangan pada kumpulan puisi Nafas karya Fatima Musawa disini memang hanya sedikit bagian atau analisis gaya bahasa yang ditemukan oleh penulis.

\section{DAFTAR PUSTAKA}

Damono, Supardi Djoko. (2015). Sastra Bandingan. Ciputat: Editum

Endaswara, Suwardi. (2014). Metodologi Penelitian Sastra Bandingan. Jakarta: Bukupop.

Ilyas, Nursam. (2011). Intisari dan Soal Bahasa dan Sastra Indonesia. Jakarta: PT Bumi Aksara.

Mualim, Fahrudin dan Erowati Rosida. (2015). Perbandingan Gaya Bahasa Pada Puisi "Ibu” Karya Mustofa Bisri dan Lirik Lagu "Keramat” Karya Rhoma Irama". Jurnal: DIALEKTIKA. 20 November 2015. ISSN: 2407-506X (http://journal.uinjkt.ac.id/index.php/dialektika )

Nurhasanah. (2017). Analisis Gaya Bahasa dalam Kumpulan Cerpen Rectoverso karya Dewi Lestari . FKIP UNTA, 1-15.

Riyanto, Yatim. (2010). Metodologi Penelitian Pendidikan. Surabaya: SIC.

Saebani, B.A. (2008). Metode Penelitian. Bandung: Pustaka Setia. 
Sugihastuti, (2016). Buku Ajar Bahasa Indonesia Akademik. Yogyakarta: Pustaka Pelajar.

Sugiyono. (2018). Metode Penelitian Kuantitatif, Kualitatif dan R\&D. Bandung: ALFABETA

Suyitno. (2009). Apresiasi Puisi dan Prosa. Surakarta: UNS Press.

Tarigan, H.G. (2009). Pengajaran Gaya Bahasa. Bandung: Angkasa.

Wirajaya, Asep Yudha. (2009). Sastra Indonesia. Bandung: Angkasa.

Zaidan, Abdul Rozak, (2007). Kamus Istilah Sastra. Jakarta: Balai Pustaka. 